\title{
Issuance of Administrative Acts by Bulgarian Authorities: Procedural Requirements Regarding the Participation of the General Public in the Process and Common Violations as Seen by National Courts
}

The rule of law in any state requires principles when it comes to regulating matters through administrative activity. Effective governance takes place when administrative authorities, in the process of issuing acts, achieve the balance between the interests of the authority and the interests of a community or private parties. As a rule, administrative bodies serve the interests of the general public and therefore acts issued by these authorities should be aimed to protect the public interest without severe interference in the lives and activities of private parties. It is not a rare situation, however, that the respective interests of the community and of members of the public pull at different directions thus making it difficult for the public authority to draw the line and find the balance between the public and private interests. That very need for proportionate and reasonable actions of the administration has led to establishing one of the basic principles in the process of issuing administrative acts: the participation of the interested parties in the procedure before the administrative authority. This is achieved by the requirement that, before issuing the act, the authority is to gather the opinions and statements of the members of the public who will be affected by the act.

This raises the following questions: what are the legal guarantees that the public is allowed to give an opinion on the content and consequences of an administrative act before its issuance and whether these guarantees are applied in practice and not only in law. This paper will analyse the rules for participation of the public in the activity of administrative authorities, both with respect to individual administrative acts and administrative acts of normative nature as well as how the participation of the public impacts the content and legal implications of the act.

1 Donka Stoyanova, $\mathrm{PhD}$ candidate, Bulgarian Academy of Sciences, Institute for Legal Studies Sofia, Bulgaria 28 Todor Alexandrov Blvd., floor 7, Telephone: +359 889 851 327, e-mail: donka.stoyanova@gmail.com. 


\section{Basic principles in administrative activity concerning the participation of the public in the issuance of administrative acts}

The guarantees for participation of the members of the public before administrative bodies in Bulgaria stem from the Constitution of the Republic of Bulgaria and are regulated in detail with specific rules in a number of statues and legislative acts.

\subsection{Constitution of the Republic of Bulgaria}

The Constitution of the Republic of Bulgaria ${ }^{2}$ sets forth the rule for judicial control over acts of the administration thus guaranteeing that the principle of participation of the public before administrative authorities is observed. Pursuant to Article 120(1) of the Constitution, national courts conduct a review of the legality of acts and actions of administrative authorities; in accordance with paragraph 2 of the same article, any natural person or legal entity is entitled to challenge acts and/or actions of the administration unless the judicial review is excluded by a statutory rule. As a result of the above rules, if an administrative authority has deprived any interested party of the possibility to take part in the issuance of administrative acts, the legality of the act will be reviewed in the light of the arguments raised by the interested parties.

\subsection{Code of Administrative Procedure}

The Code of Administrative Procedure ${ }^{3}$ contains the basic principles concerning administrative activity and issuance of acts, such as independence and impartiality of the administration, acting within the remit determined in law, publicity and transparency as well as proportionality and predictability. The Code of Administrative Procedure also specifies in detail the procedure and requirements for issuance of three types of administrative acts: individual, general and normative. In particular, Articles 26 and 35 of the Code of Administrative Procedure set forth the specific rules to be followed by the administrative authority as regards the participation of the interested parties before issuance of an individual administrative act, whereas Article 66 and Article 77 thereof regulate the same with respect to the issuance of general and normative administrative acts.

2 The Constitution of the Republic of Bulgaria, OJ, issue No. 56 of 13.07.1991, last amendment OJ, issue No. 100 of 18 December 2015.

3 The Code of Administrative Procedure, OJ, issue No. 30 of 11.04.2006, last amendment OJ, issue No. 74 of 20 September 2016. 


\subsection{Normative Acts Law}

The procedure and requirements set forth in the Normative Acts Law ${ }^{4}$ are applicable for issuance of all administrative acts except for individual administrative acts. The rules of the Normative Acts Law are applied in parallel with the rules set forth in the Code of Administrative Procedure, especially given the fact that the Normative Acts Law specifies in detail the stages to be followed by the administrative authority. In particular, Articles 26 and 28 thereof specify the terms for public consultations that should be held before the adoptions of the act and the requirements as to the content of the draft act and the motives to it which is directly linked to the general public becoming acquainted with the reasons for the adoption of the act and submitting statements or objections.

\section{Participation of members of the public in the process of issuance of individual administrative acts}

As a rule, the circle of participants in the process of issuance of individual administrative acts is rather limited compared to the procedures for issuance of administrative acts of normative nature, mainly because the circle of interests concerned is narrowed down to the applicant and the persons directly affected by the consequences of the act (who are not its addressees). Nevertheless, the administrative authority is not released from the responsibility and obligation to notify and request the opinion of all interested parties that may be affected by the administrative act to be issued - this includes both the potential addressees and other persons who are not the addressees of the act but their legal standing or rights are affected by it. As a rule, the more diligent the administrative authority in allowing the potentially affected persons to participate by filing statements or objections to the content of the administrative act, the higher the chances that such an act will withstand a potential challenge and judicial review.

This is so, because the procedure for issuance of administrative acts in Bulgaria is regulated in such a way that even if the interested parties have been deprived of the possibility to submit their objections or statements to the administrative body before the issuance of an administrative act, they are still entitled to challenge the act before national administrative courts. Therefore, they have the right to present their position or objections to the court which will review them in the light of the issued act. The members of the public directly affected by the administrative act issued are parties to the judicial review, even if their participation has been ignored by the administrative body, pursuant to Article 120 of the Constitution of the Re-

4 Normative Acts Law, OJ, issue No. 27 of 03.04.1973, last amendment OJ, issue No. 34 of 03 May 2016. 
public Bulgaria any act which is not excluded from judicial review by law is subject to a challenge. It should be noted that very few administrative acts are excluded from judicial review in Bulgaria and they are mainly related to national security and similar matters because of the prevailing interest of the state's interests as opposed to those of the general public. Therefore, the participation of the affected members of the public in the course of issuance of acts is practically unavoidable - if the administrative body has failed to consider their statements or has excluded their participation for some reason, the court will review their considerations, thus affecting the final outcome of the administrative act for them and the other interested parties.

Article 35 in conjunction with Article 26 of the Code of Administrative Procedure guarantee the participation of both the person to whom the act is addressed and the public in the process of its issuance. Article 26 of Code of Administrative Procedure provides that upon initiating the administrative procedure the administrative authority is obliged to inform the addressee as well as the known members of the public who may be affected by the act of the procedure launched. Furthermore, Article 35 of the Code of Administrative Procedure requires the administrative authority to consider all facts and circumstance related to the case, which includes a review of statements or objections submitted by the addressee of the act and the interested parties.

As a rule, in the absence of such notification the interested parties do not participate in the administrative procedure while the authority does not enjoy a full view of the facts and circumstances that should be taken into consideration before deciding on the matter. The omission to let the public participate in the process is considered as insignificant only when the interested parties do not have any new evidence or information that is relevant for the matter, so the administrative act would have the same content irrespective of their participation ${ }^{5}$.

In contrast to the above, in most cases the Supreme Administrative Court has taken the view that depriving the addressee or potentially affected persons of their right to submit objections or statements on the matter constitutes a substantial violation of the procedure and thus a ground for the repealing of the administrative act. Such are the conclusions of the court in a case where the administrative measure of compulsion "prohibition to

5 "Given the relevant facts and the competence of the administrative authority, the appellant would not have been able to present any fact or evidence, different from those reviewed by the administrative authority. This is confirmed by the fact that the appellant has not presented any new evidence or statements in the course of the judicial appeal against the administrative act before two court instances" - as per reasons for Decision 9327 of 27 June 2012, case 10300/2011, Cassation Panel of the Supreme Administrative Court of Bulgaria. The decision is publicly available at the official Internet site of Supreme Administrative Court. 
leave the country" was reviewed following a complaint from the addressee of the act ${ }^{6}$.

When imposing a compulsory administrative measure, the authority is obliged to consider all facts and circumstances related to the specific case and by depriving the addressee of the possibility to state their position, the authority has in practice issued an act without justification. Its absence, in turn, prevents the court from performing a full judicial review of the legality of the administrative act, i.e. checking whether the compulsory measure was implemented according to the conditions set in law and whether the principle of proportionality has been followed.

The requirement of proportionality in administrative activity is one of the principal rules that guarantee the balance between the interests of the addressee of the act and those of the general public (in whose interest the administrative body acts by default). The principle of proportionality set forth in Article 6 of the Code of Administrative Procedure encompasses several aspects: the authorities should exercise their powers in good faith and in favour of justice; the administrative act and its enforcement cannot affect rights and legally binding interests more than what is most necessary for achieving the purpose of the act; when the administrative act is to affect rights and legally binding interests of the parties, the administrative authority is required to choose measures that are most favourable for the persons affected by the act. On the matter of proportionality, the Constitutional Court of the Republic of Bulgaria stated in its Decision No. 2 of 31 March 2011 that, when it comes to imposing administrative measures of compulsion, automatic and indefinite in terms of time application, measures such as prohibition to leave the country significantly restrict the right of free movement of the addressee and therefore are excessive and inappropriate for achieving the purposes set in law. The European Court of Human Rights in a number cases against Bulgaria ${ }^{7}$ has also declared that administrative authorities not always strictly observe the principle of proportionality when applying compulsory administrative measures ${ }^{8}$.

6 "Without being notified about the initiation of the procedure for the issuance of an act, which in its essence directly affects their legally guaranteed right (of free movement), the addressee cannot effectively exercise their right to defense" - as per the reasons for Decision No. 209 of 08 January 2013, case 6630/2012, Cassation Panel of the Supreme Administrative Court. The decision is publicly available at the official Internet site of Supreme Administrative Court.

7 European Court of Human Rights, case of Riener vs. Bulgaria, appl. 46343/99; case of Gochev vs. Bulgaria, appl. 34383/03.

8 "The Court considers that the "automatic « nature of the travel ban ran contrary to the authorities' duty under Article 2 of Protocol No. 4 to take appropriate care that any interference with the right to leave one's country should be justified and proportionate throughout its duration, in the individual circumstances of the case (...). Regardless of the approach chosen, the principle of proportionality must apply, in law and in practice" - European Court of Human Rights, Judgement of 23 May 2006, case of 
If we go back to the case with the Bulgarian citizen prohibited to leave the country, the lack of notification by the administrative authority about the initiated procedure led to the impossibility of the person affected to present evidence and information in his defence and thus to affect the final outcome of the act. In the particular case, the prohibition to leave the country was imposed on the Bulgarian citizen because he was sentenced by a Serbian court to nine-month imprisonment for illegal smuggling of drugs. The administrative measure of compulsion was applied by the administrative body (a department of the Ministry of Inferior) when exercising its operative discretion, without the Serbian state requesting expulsion or other measures with respect to the sentenced Bulgarian citizen. In these circumstances, by depriving the addressee of the act of the right to participate in the procedure before the administrative body, the latter failed to consider the particular behaviour of the addressee of the act and to apply the principle of proportionality. Thus, the administrative body imposed restrictions on the citizen's right of free movement, a basic right as per Article 21 of the Treaty on the Functioning of the European Union, without clear purpose and for the sake of general prevention only, which in turn implied the excessiveness of the measure.

Had the administrative authority allowed for the addressee of the act to participate in the procedure, the outcome of the procedure might have been different. Allowing the addressees of the act to submit statements to the administrative authority before the issuance of the act means observance of their right of defense from the very beginning of the procedure. Thus, insofar as the right of defense is protected under Article 46 and 47 of the Charter of the Fundamental Rights of the European Union, the provision of Article 26 in conjunction with Article 35 of the Code of Administrative Procedure is practically aimed at observing the basic principles of EU law.

\section{Participation of members of the public in the process of issuance of administrative acts of normative nature}

Before conducting the analysis, a note should be made on the nature of administrative acts issued by Bulgarian authorities and addressed to an indefinite number of parties: there is a legal classification of administrative acts, depending on their application in time and with respect to the persons affected.

The first type are administrative acts of normative nature where the act applies to an indefinite number of addressees and is applied without

Riener vs. Bulgaria, appl. 46343/99, paragraph 128; European Court of Human Rights, Judgement of 26 February 2010, case of Gochev vs. Bulgaria, appl. 34383/03, par. 57. 
limitation in time (until it is repealed) ${ }^{9}$. Such acts are various ordinances issued by the Council of Ministers and ministers; instructions; the National Framework Contract, issued by the National Health Insurance Fund regarding the terms and conditions for delivery of medical services, etc. ${ }^{10}$

The second type of administrative act are "general administrative acts" ${ }^{11}$ where the act applies to an indefinite, but subject to determination, number of addressees and has one-off effect as to its legal consequences (i.e. the rights or obligations originate from the act and the addressees should comply with them for a certain period of time) ${ }^{12}$. An indefinite but subject to determination number of addresses means that the addressees could be identified by characteristics specified in the act so that the legal effect of the act is limited only to the persons who qualify as per these characteristics. For instance, general administrative acts are various orders of mayors of municipalities in Bulgaria that impose certain restrictions or specific rules for the residents of a municipality, town or village; a construction supervision authority's prohibition to build for a certain period of time and in a certain area (i.e. during the winter season at Bulgarian ski resorts); various instructions of the police and fire departments regarding organisation of traffic and safety procedures. As a rule, these acts apply for a period of time specified in the act itself. There are few general administrative acts which, by operation of law, are applied indefinitely in time until they are repealed (explicitly or by the issuance of a new act dealing with the same matter) - i.e. certain decisions of the Bulgarian Communications Regulations Commission with respect to the regulation of electronic communications services on various markets or acts of the Bulgarian National Bank concerning specific obligations of the financial institutions subject to supervision.

Both normative and general administrative acts and the procedure for their issuance is dealt with in the present section of the paper since the rules guaranteeing the participation of the general public are the same; they are applied in the same way by Bulgarian courts and violation of these rules are equally considered violations of the procedure, which are significant enough to justify the repealing of the act.

9 Article 75(1) of the Code of Administrative Procedure, OJ issue No. 30 of 11 April 2006, last amendment OJ issue No. 74 of 20 September 2016.

10 A. Elenkov, A. Angelov, A. Djulgerov, A. Disheva, L. Panov, M. Kazandzhieva, S. Yankulova, T. Nikolova, J. Kovacheva, Administrative Procedure Code, Systematic comments and analysis of the case law, "Trud i Pravo" Publishing House, Sofia 2013, p. 642-654.

11 Article 65 of the Code of Administrative Procedure, OJ issue No. 30 of 11 April 2006, last amendment OJ issue No. 74 of 20 September 2016.

12 A. Elenkov, A. Angelov, A. Djulgerov, A. Disheva, L. Panov, M. Kazandzhieva, S. Yankulova, T. Nikolova, J. Kovacheva, Administrative Procedure Code..., p. 592-610. 
In contrast to the procedure for the issuance of individual administrative acts where the numbers of addressees or interested parties is limited to a particular case, the circle of persons affected by general and normative administrative acts is by default significantly wider. This requires setting up a procedure where the public is given the possibility to participate in the process of the issuance of the act and thus to be able to influence its content ${ }^{13}$. At the same time, the administrative authority should be relieved from the obligation to notify individually any of the potentially affected persons and parties simply because in most cases the authority would not be able to identify them in a comprehensive manner.

The above is achieved through Article 26 of the Normative Acts Law which provides that in the course of the issuance of a normative administrative act public consultations with natural persons and organisations are carried out. For that purpose, the administrative authority publishes a draft administrative act, together with its justification, a report and preliminary assessment of the results of the application of the act on the Internet site of the authority. If the administrative authority is part of the executive power, all draft administrative acts are to be published on the Public Consultations Portal which is supported by the Council of Ministers. The Public Consultations Portal supports an official Internet site and its aim is to provide a united database for all pending procedures for the issuance of administrative acts so that the interested parties can easily find potential administrative acts concerning them. The drafts are also published on the Internet site of the respective issuing authority (irrespective of the publication on the Internet site of the Public Consultations Portal). The Public Consolations Portal is not applicable to authorities outside of the executive power in Bulgaria, i.e. mayors and municipal councils - in this case the draft act is published only on the Internet site of the respective municipality.

As regards general administrative acts, Article 77 of the Code of Administrative Procedure further details that, apart from publishing the draft on the Internet site, the administrative authority could also publish the materials in mass media or could send the draft to known organisations or persons who may be affected by the act. Following the publication of the draft, the members of the general public who are potential addressees or parties affected by the application of the act, are allowed to submit statements, objections and even proposals for amending the wording of the provisions of the act. Following the expiration of the term for public consultations, the authority reviews the statements and proposals for amendments of the act and adopts a final draft of the act which is to be published in the State Gazette.

13 OECD, Administrative Procedures and the Supervision of Administration in Hungary, Poland, Bulgaria, Estonia and Albania, SIGMA Papers, No. 17, OECD Publishing, Paris 1997, http://dx.doi.org/10.1787/5kml6198lvkf-en. 
Although the rule of Article 26 of the Normative Acts Law seems easy to comply with, its violation is one of the most common reasons for repealing normative and general administrative acts in Bulgaria. The most common violations on the part of administrative authorities are related to failure to publish all enclosures (motives, report, etc.) to the draft act; sometimes, the authority publishes a draft with due justification yet they simply repeat the provisions of the draft and do not give any specific information about the reasons for the adoption of the act and the purposes that are pursued with the act; the authority adopts the act making significant amendments to the initially published draft without publishing the amended draft for public consultations. All of the abovementioned omissions of administrative authorities are considered significant violations because they effectively limit the possibilities of the interested parties to influence the final content of the act, i.e. their participation is allowed by the administrative authority only formally.

An example for a public consultations procedure that is only formally followed is when the authority publishes a draft administrative act with a report and motives and the latter simply repeat the provisions of the act. The guarantee for members of the public to be able to understand the exact reasons for the adoption of an act is provided in Article 28 of the Normative Acts Law. In particular, the justification of the draft act have to include: the reasons that require the adoption of the administrative act; the purposes which are pursued with the act; financial and other means and materials necessary for the application of the act; expected results; analysis of the compatibility of the provisions of the act with the EU law. If the motives do not fulfil any or all of the above requirements, then in practice the draft act is not accompanied by a justification ${ }^{14}$.

Another requirement that is relatively often ignored and thus violated by administrative authorities is that the purpose of public consultations is to give the general public the possibility to get acquainted with the content of the act as it is to be published in the State Gazette. Therefore, if after the initial publication for public consultations the act has been amended (as a result of the statements and proposals of the interested parties or on the initiative of the administrative authority), then the administrative authority should publish the amended draft of the act for another round of public

14 In this regard, the reasoning of the court in Decision 7707 of 25 June 2015, case 1132/2015 of Cassation Panel of the Supreme Administrative Court: "The requirements to the content of the justification of a normative administrative act are not for their own sake. These requirements are the instrument and the guarantee that the basic principles for issuance of administrative act are followed - the principles for a well-grounded act, stability, transparency and stability. The lack of the statutorily required content in the reasons, apart from being formally not compliant with Article 28 of the Normative Acts Law, dienies the court the possibility to analyse if the adoption of the act has been done in accordance with the abovementioned principles". 
consultations. Otherwise, the second draft would be enforced without the participation of the public in its issuance of the act ${ }^{15}$.

As evident from the above, the authorities are obliged to observe the principles of administrative activity as per the Code of Administrative Procedure without any exception. What is more, Article 26(1) of the Normative Acts Law obliges the administration to further follow the principles of necessity, reasonableness, predictability, transparency, subsidiarity, proportionality and stability in the process of issuing administrative acts. It follows from the above that only when the procedure concerning the public consultations is effectively followed, could the principles of administrative activity be complied with and the public interest protected.

To summarise the above, the work of the administration should always be carried out in favour of the parties affected by that activity. When issuing individual administrative acts, the authorities should take account of the interests of the addressee and the parties potentially affected by the act, and when issuing general and normative administrative acts the administration should take account of the interests of the general public. In both cases, this can be achieved only through allowing members of the public to participate in the decision-making process through submitting their positions or objections prior to the issuance of the final administrative act. Whereas the guarantee for proper and diligent work of the administration is the participation of the public in its activity, the guarantee that the administration will not ignore this requirement is the constitutional principle that, except for a limited number of cases, all acts and actions of the administration are subject to judicial review.

\section{List of references}

Code of Administrative Procedure, OJ, issue No. 30 of 11.04.2006, last amendment OJ issue No. 74 of 20 September 2016.

Decision 9327 of 27 June 2012, case 10300/2011, Cassation Panel of the Supreme Administrative Court of Bulgaria.

15 As per reasons for Decision 78 of 6 January 2014, case 8815/2013, Cassation Panel of Supreme Administrative Court: "The circumstances of the case show that following the first publication for public discussion, the municipal council has approved amendment of a provision of the ordinance which was not provided in the initial draft of the act. The procedure for the adoption of a normative administrative act is provided in law in the interest of the general public, therefore the omission is a substantial violation of the procedure for the adoption of administrative acts. Compliance with the imperative rules regarding the issuance of an administrative act is a responsibility of the administration vested with executive powers where the latter should be guided by the principles of rule of law, equality, accessibility, publicity and transparency as per Articles 4, 8 and 12 of the Code of Administrative Procedure". Further, Decision 3444 of 12 March 2013, case 1258/2012, Third Division of Supreme Administrative Court. The decisions are available on the official Internet site of Supreme Administrative Court. 
Decision No. 209 of 8 January 2013, case 6630/2012, Cassation Panel of the Supreme Administrative Court of Bulgaria.

Decision 7707 of 25 June 2015, case 1132/2015 of Cassation Panel of the Supreme Administrative Court of Bulgaria.

Decision 3444 of 12 March 2013, case 1258/2012, Third Division of Supreme Administrative Court of Bulgaria.

Elenkov A., Angelov A., Djulgerov A., Disheva A., Panov L., Kazandzhieva M., Yankulova S., Nikolova T., Kovacheva J., Administrative Procedure Code, Systematic comments and analysis of the case law, "Trud i Pravo" Publishing House, Sofia 2013.

European Court of Human Rights, Judgement of 23 May 2006, Case of Riener vs. Bulgaria, appl. 46343/99.

European Court of Human Rights, Judgement of 26 February 2010, case of Gochev vs. Bulgaria, appl. 34383/03.

OECD, Administrative Procedures and the Supervision of Administration in Hungary, Poland, Bulgaria, Estonia and Albania, SIGMA Papers, No. 17, OECD Publishing, Paris 1997, http://dx.doi.org/10.1787/5kml6198lvkf-en.

The Internet site supported by the Public Consultations Portal can be found at www.strategy.bg.

Normative Acts Law, OJ, issue No. 27 of 03 April 1973, last amendment OJ, issue No. 34 of 3 May 2016.

The Constitution of the Republic of Bulgaria, OJ, issue No. 56 of 13 July 1991, last amendment OJ, issue No. 100 of 18 December 2015.

Abstract

The work of the administration should serve the interests of the parties involved and of the public. That very need for proportionate and reasonable actions of the administration has led to establishing one of the basic principles in the process of issuing administrative acts, the participation of the interested parties in the procedure before the administrative authority. This is achieved by the requirement that, before issuing the act, the authority is to gather the opinions and statements of the members of the public who will be affected by it and to reflect them in the final act. The guarantee that members of the public will be allowed to participate in the procedure and influence the final content of the act is the judicial review of the administrative act.

Keywords: administrative activity, public interest, individual administrative act, general administrative act, normative administrative act, participation of members of the public

\section{Decyzje administracyjne wydawane przez bułgarskie władze: wymogi proceduralne dotyczące uczestnictwa obywateli w procesie decyzyjnym oraz powszechne naruszenia widziane z perspektywy sądów krajowych \\ Streszczenie}

Praca sektora administracji powinna służyć interesom zainteresowanych stron oraz ogółu społeczeństwa. Właśnie ta potrzeba proporcjonalnych i racjonalnych działań administracji doprowadziła do ustanowienia jednej z podstawowych zasad w procesie 
wydawania decyzji administracyjnych i uczestnictwa zainteresowanych stron w postępowaniu toczącym się przed organem administracyjnym. Do osiągnięcia tego ceku przyczynia się wymóg, by przed wydaniem decyzji organ zgromadził opinie i oświadczenia osób, na które będzie ona wpływać, oraz odzwierciedlił je w końcowej decyzji. Gwarancję dopuszczenia obywateli do udziału w postępowaniu i wpływania na ostateczną treść decyzji stanowi kontrola sądowa decyzji administracyjnej.

Słowa kluczowe: działalność administracyjna, interes publiczny, jednostkowa decyzja administracyjna, ogólna decyzja administracyjna, decyzja administracyjna o charakterze normatywnym, uczestnictwo ogółu społeczeństwa 